\title{
THE ROLE OF ROOT PLANT ARCHITECTURE IN LANDSLIDE AND EROSION DISASTER MITIGATION
}

\section{PERANAN ARSITEKTUR AKAR TANAMAN DALAM MITIGASI BENCANA GERAKAN TANAH DAN EROSI}

\author{
Euthalia Hanggari Sittadewi ${ }^{1}$ dan Iwan G. Tejakusuma ${ }^{1}$ \\ ${ }^{1}$ PTRRB - TPSA - BPPT, JI. M. H. Thamrin No. 8, Jakarta 10340, email: sittadewi57@gmail.com
}

\begin{abstract}
Landslide and erosion disasters become increasingly common in the last decade which resulted in financial losses and even human casualties. Therefore, disaster mitigation efforts of landslide and erosion are very important to be done immediately. A breakthrough of comprehensive and practical solution is highly expected for mitigation. Vegetation can improve slope stability, provide positive aspects for the environment, and provide mechanical and hydrological effects on slopes that are prone to landslide and erosion. The use of vegetation to mitigate landslide and erosion disasters is very potential to be developed because besides being effective, it is also economical and environmentally friendly. The mechanical aspects of plant roots is able to strengthen the soil. Plant root characteristics such as root architecture, root anchor index (IJA), root grip index (ICA) are important variables to determine the types of plants that will be used in mitigating landslide and erosion.
\end{abstract}

Keywords: root architecture, mechanical roots, root anchor index, root grip index, mitigation of landslide and erosion

\begin{abstract}
ABSTRAK
Bencana gerakan tanah dan erosi semakin sering terjadi pada dekade terakhir ini yang mengakibatkan kerugian finansial bahkan korban jiwa manusia. Oleh karena itu upaya mitigasi bencana gerakan tanah dan erosi menjadi sangat penting untuk segera dilakukan. Solusi yang komprehensif dan praktis diterapkan merupakan terobosan yang sangat diharapkan untuk mitigasi tersebut. Vegetasi dapat meningkatkan stabilitas lereng, memberikan aspek positif di bidang lingkungan, serta memberikan efek mekanik dan hidrologi pada lereng yang rawan gerakan tanah dan erosi. Penggunaan vegetasi untuk mitigasi bencana gerakan tanah dan erosi sangat potensial untuk dikembangkan karena selain efektif, juga ekonomis dan ramah lingkungan. Aspek mekanik perakaran tanaman berfungsi menguatkan tanah. Karakteristik perakaran tanaman seperti arsitektur akar, indeks jangkar akar (IJA), indeks cengkeram akar (ICA) merupakan variabel penting untuk menentukan jenis tanaman yang akan digunakan dalam mitigasi gerakan tanah dan erosi.
\end{abstract}

Kata kunci: arsitektur akar, mekanik perakaran, indeks jangkar akar, indeks cengkeram akar, mitigasi gerakan tanah dan erosi 


\section{PENDAHULUAN}

Perubahan iklim dan pola curah hujan yang berubah serta meningkatnya aktifitas manusia merupakan faktor penting yang menyebabkan terjadinya bencana gerakan tanah dan erosi di Indonesia. Pemindahan atau perubahan vegetasi pada lereng misalnya sering menjadi pemicu terjadinya gerakan tanah dan erosi selain faktor yang menjadi pengendali utama yaitu sifat dasar batuan dan tanah, konfigurasi dan geometri lereng serta kondisi air tanah. Untuk mengurangi risiko akibat bencana gerakan tanah dan erosi, dibutuhkan adanya solusi yang komprehensif. Pemanfaatan vegetasi dapat menjadi pilihan yang potensial karena merupakan cara yang efektif, ekonomis dan ramah lingkungan.

Dalam hubungannya dengan kestabilan lereng, fungsi tanaman secara keseluruhan dapat memberikan efek penting yaitu efek hidrolik dan efek mekanik. Akar yang merupakan bagian dari tanaman juga dapat memainkan perannya untuk memberikan efek hidrolik dan mekanik terhadap kestabilan lereng. Fungsi akar tanaman dalam menyerap air dari tanah dan melepaskan ke atmosfer melalui mekanisme transpirasi yang menyebabkan air pori berkurang merupakan efek hidrologis yang dapat meningkatkan stabilitas lereng. Monteleone dan Sabatino (2014) mengatakan bahwa efek hidrolik akar tanaman yang relevan dalam mitigasi bahaya gerakan tanah adalah stabilisasi tanah secara vertikal. Efek mekanis dari akar tanaman pada stabilitas lereng adalah menstabilkan lereng dengan penguatan mekanis tanah. Akar tanaman akan memperkuat tanah dan meningkatkan kekuatan geser tanah. Dalam kaitannya dengan peran akar terhadap stabilitas tanah, Chirico et al. (2013) mengatakan bahwa pada dasarnya ada dua mekanisme dominan yaitu: (1) penyerapan air oleh akar, yang berkontribusi untuk meningkatkan stabilitas dengan meningkatkan resistensi gesekan yang terkait dengan pengisapan tanah dan (2) penguat tanah oleh struktur akar, yang meningkatkan stabilitas dengan memberikan kohesi tambahan pada tanah.

Karakteristik fisik dari akar tanaman yang mempengaruhi kekuatan geser tanah adalah distribusi, kepadatan, diameter, berat jenis, dan kekuatan akar (Hairiah et $a_{-}$., 2008). Semakin tinggi konsentrasi akar berserat membuat tanaman akan lebih kuat terhadap tanah (Azizi dan Salim, 2015). Sedangkan besarnya kekuatan geser tanah dipengaruhi oleh kondisi tanah yaitu kelembaban, fraksi liat, dan porositas serta karakteristik akar tanaman (Collison dan Pollen, 2005).

Kemampuan penetrasi akar dalam lapisan tanah juga merupakan karakteristik akar yang penting untuk pengendalian gerakan tanah. Akar vertikal dan akar horizontal yang mampu menembus lapisan tanah lebih dalam akan memberikan kenaikan stabilitas lereng, khususnya tipe gerakan tanah dangkal. Peran akar ini akan lebih efektif apabila akar tersebut memotong bidang longsor potensial. Hairiah et al. (2008) mengatakan bahwa peran akar dalam pengendalian gerakan tanah hanya efektif untuk kejadian gerakan tanah tipe dangkal yaitu kurang dari 3 meter atau gerakan tanah permukaan. Sedangkan kejadian gerakan tanah dalam lebih dipengaruhi oleh kondisi geologi dan iklim.

Dengan mempertimbangkan kemampuan akar dari aspek hidrolik dan mekanik serta karakteristik fisik dan sistem perakaran tanaman maka jenis tanaman tertentu dapat dimanfaatkan untuk mitigasi gerakan tanah dan erosi khususnya gerakan tanah tipe dangkal. Makalah ini bertujuan untuk mengetahui peran efek perakaran tanaman dalam mitigasi gerakan tanah dan erosi dengan pembahasan terutama dari aspek mekanik perakaran tanaman dan variabel karakteristik perakaran untuk memilih tanaman yang berpotensi dalam mitigasi gerakan tanah dan erosi.

\section{METODE}

Studi tentang efek perakaran tanaman dalam mitigasi gerakan tanah dan erosi dilakukan dengan beberapa langkah dan metode sebagai berikut-:

1. Melakukan studi pustaka atau literatur baik tentang data, informasi, maupun penelitian sebelumnya melalui penelusuran jurnal, buku atau website terkait pokok bahasan.

2. Mendeskripsikan tentang sistem perakaran, dan arsitektur perakaran tanaman dalam hubungannya dengan efek stabilitas.

3. Mendeskripsikan tentang aspek mekanik dan hidrolik dari perakaran tanaman.

4. Mendeskripsikan jenis tanaman dengan variabel karakteristik perakaran yang berpotensi meningkatkan stabilitas lereng sebagai langkah mitigasi gerakan tanah dan erosi khususnya gerakan tanah tipe dangkal.

5. Menganalisis dan menyimpulkan hasil deskripsi secara keseluruhan tentang 
potensi perakaran tanaman dalam mitigasi gerakan tanah dan erosi.

\section{HASIL DAN PEMBAHASAN}

\subsection{Mitigasi Bencana Gerakan Tanah dan Erosi Dengan Vegetasi}

Gerakan tanah adalah peristiwa geologi yang terjadi karena pergerakan masa batuan atau tanah dengan berbagai tipe dan jenis seperti jatuhnya bebatuan atau gerakan tanah. Gerakan tanah terjadi karena dua faktor utama yaitu faktor pengontrol dan faktor pemicu. Faktor pengontrol adalah faktor-faktor yang mempengaruhi kondisi material itu sendiri seperti kondisi geologi, kemiringan lereng, litologi, sesar dan kekar pada batuan. Faktor pemicu adalah faktor yang menyebabkan bergeraknya material tersebut seperti curah hujan, gempa bumi, erosi kaki lereng dan aktivitas manusia.

Erosi adalah peristiwa pengikisan padatan (sedimen, tanah, batuan, dan partikel lainnya) akibat transportasi angin, air atau es, karakteristik hujan, creep pada tanah dan material lain di bawah pengaruh gravitasi, atau oleh makhluk hidup, sebagai contoh hewan yang membuat liang, dalam hal ini disebut bio-erosi.

Dengan terus meningkatnya kejadian gerakan tanah dan erosi yang mengakibatkan kerugian terhadap manusia, maka langkah langkah mitigasi harus terus dilakukan. Pengkajian penggunaan vegetasi dalam mitigasi gerakan tanah dan erosi belum banyak dilakukan khususnya penggunaan vegetasi yang tepat. Vegetasi mempunyai keunggulan karena mudah didapat, ramah lingkungan dan ekonomis bila dibandingkan dengan teknik pembuatan struktur sipil. Oleh karena itu kajian tentang efektivitas vegetasi dalam mitigasi bencana gerakan tanah dan erosi perlu secara terus menerus dilakukan.

Menurut Huat dan Sina (2010) beberapa aspek positif dapat diambil jika dilakukan pengelolaan vegetasi untuk penutup lereng yaitu :

1. Aspek lingkungan melalui peningkatan penyerapan karbon untuk mengurangi kenaikan tingkat karbon dioksida $\left(\mathrm{CO}_{2}\right)$ di atmosfer yang umumnya membawa pemanasan global.

2. Aspek mekanik melalui penguatan tanah oleh akar tanaman dapat mencegah erosi permukaan tanah dan gerakan tanah.

3. Aspek hidrologi melalui pengurangan limpasan oleh intersepsi air hujan selama hujan berlangsung sehingga meminimalkan masuknya air ke lereng. Dengan menjaga infiltrasi air ke dalam tanah pada kemiringan lereng dalam periode yang lama akan menjaga kestabilan lereng.

Penggunaan vegetasi untuk mitigasi bencana gerakan tanah dan erosi belum banyak dilakukan di Indonesia walaupun potensinya besar dari segi ketersediaan sumber_daya, lebih murah secara ekonomi dan banyak keuntungan lingkungan. Studi yang telah dilakukan diantaranya oleh Sittadewi (2010) yang meneliti tentang perlindungan tebing Sungai Siak. Susilawati dan Veronika (2016) juga telah melakukan pengamatan pada lereng hasil rekayasa manusia yaitu pemotongan lereng untuk pembuatan jalan di rute jalan Ende sampai Aegela, di Provinsi Nusa Tenggara Timur. Demikian pula Laela et al. (2014) yang meneliti soil bioengineering untuk kestabilan lereng pada jalur jalan Tawaeli - Tobolo di Sulawesi Tengah. Sementara itu Zakaria et al. (2013) memberikan pandangan tentang pemanfaatan tanaman Kaliandra (Calliandra calothyrsus) untuk pencegahan gerakan tanah dan kegunaan lainnya dari tanaman tersebut bagi masyarakat sekitarnya.

\subsection{Efek Mekanik Dan Hidrolik Perakaran Tanaman}

Vegetasi memberikan kontribusi yang cukup signifikan dalam mitigasi gerakan tanah dan erosi melalui mekanisme secara hidrologis dan mekanis. Mekanisme hidrologis dan mekanis sejalan dengan fungsi dari bagian - bagian tanaman seperti akar, batang dan daun. Vegetasi dapat mempengaruhi stabilitas lereng ketika akar tanaman bertindak sebagai penguat tanah (Huat dan Sina, 2010). Demikian juga Ziemer (1981) mengatakan bahwa efek dari vegetasi untuk stabilisasi -lereng adalah dengan penguatan mekanis tanah melalui akar sebagai aspek mekanis. Selain dampak mekanis, juga dari dampak hidrologis dengan pengurangan kadar air tanah melalui transpirasi, intersepsi curah hujan (Greenway, 1987).

Adapun mekanisme hidrolik dan mekanik oleh akar tanaman untuk meningkatkan stabilitas lereng dapat dikemukakan sebagai berikut-:

1. Akar menyerap air dari tanah, air yang hilang ke udara oleh transpirasi, menyebabkan tekanan air pori berkurang, sehingga meningkatkan stabilitas lereng. Hal ini sesuai dengan yang dikatakan oleh Monteleone dan 
Sabatino (2014) bahwa stabilisasi tanah secara vertikal juga dilakukan oleh sistem perakaran tanaman dan juga efek drainase yang terjadi melalui proses absorpsi air dan transpirasi.

2. Dampak mekanis dari vegetasi pada stabilitas lereng adalah menstabilkan lereng dengan penguatan mekanis tanah melalui akar sebagai aspek mekanis. Akar memperkuat tanah, menambah kuat tahanan geser atau meningkatkan kekuatan geser tanah. Pengikatan akar yang kuat berpotensi lebih signifikan untuk menjaga stabilitas lereng.

3. Akar tanaman menembus sampai ke lapisan tanah dalam, memberikan dukungan pada tanah bagian atas karena berfungsi sebagai penyangga (buffering) dan memberi efek lengkung (arching). Keberadaan perakaran mampu memperbaiki kondisi sifat tanah yang disebabkan oleh penetrasi akar ke dalam tanah, menciptakan habitat yang baik bagi organisme dalam tanah, sebagai sumber bahan organik bagi tanah dan memperkuat daya cengkeram terhadap tanah (Agus et al. 2002).

4. Akar mengikat partikel tanah di permukaan dan menambah kekasaran permukaan sehingga mengurangi kemudahan tererosi. Perakaran tanaman juga membantu mengurangi air tanah yang jenuh oleh air hujan, memantapkan agregasi tanah sehingga lebih mendukung pertumbuhan tanaman dan mencegah erosi, sehingga tanah tidak mudah hanyut akibat aliran permukaan, meningkatkan infiltrasi, dan kapasitas memegang air.

\subsection{Arsitektur Perakaran dan Efek Stabilitas}

Arsitektur perakaran, yang disebut juga morfologi akar, merupakan bentuk keseluruhan dari akar suatu tanaman. Arsitektur perakaran dapat mempengaruhi peningkatan kekuatan geser yang diberikan oleh akar. Hal ini dikarenakan kontribusi akar dalam proses pergeseran tanah dipengaruhi oleh pergerakan tegangan dalam akar. Sistem perakaran secara mekanis memperkuat tanah dengan memindahkan tegangan geser pada tanah ke ketahanan tarik pada akar. Menurut Reubens et al. (2007) karakteristik suatu akar tanaman yang dapat digunakan untuk menggambarkan arsitektur perakaran antara lain adalah pola percabangan akar. Pola percabangan memiliki hubungan yang erat dengan kekuatan penjangkaran (Stoke et al., 1996). Dikatakan pula oleh Reubens et al. (2007) bahwa sistem arsitektur perakaran dengan karakteristiknya seperti kerapatan akar, jumlah akar, kedalaman akar, pola percabangan akar, sudut kemiringan akar dan diameter akar akan mempengaruhi proses gerakan tanah.

Yen (1987) membuat klasifikasi pola perakaran tanaman atau arsitekstur perakaran tanaman yang kemudian dimodifikasi oleh $\mathrm{Li}$ et al. (2016). Terdapat 6 tipe arsitektur perakaran tanaman yaitu tipe $\mathrm{H}, \mathrm{R}, \mathrm{V}-\mathrm{H}, \mathrm{V}$, $M$ dan tipe $W$. Setiap tipe arsitektur perakaran tanaman memiliki fungsi yang berbeda dalam hal kaitannya dengan mitigasi pengurangan risiko bencana gerakan tanah dan erosi.

Dalam kaitannya dengan pengaruh arsitektur perakaran dengan efek stabilitas, hasil penelitian Ali (2010) terhadap 3 spesies tanaman tropika yang mempunyai tipe arsitektur yang berbeda memberikan efek stabilitas yang berbeda. Acasia -mangium dengan arsitektur akar tipe-H (Gambar 1) memiliki tiga peran dalam stabilisasi lereng yaitu penguatan tanah, stabilitas lereng dan hambatan angin, dikarenakan sebagian besar akarnya tumbuh secara horizontal. Leucaena leucocephala dengan arsitektur akar tipe-VH (Gambar 1) mempunyai peran penguatan tanah dan stabilitas lereng. Sebagai perbandingan, arsitektur akar Leucaena leucocephala lebih menonjol karena memiliki efek penguatan gabungan baik dari akar tap dan lateral yang membentuk masing-masing secara vertikal dan horizontal. Melastoma malabathricum walaupun memiliki akar dangkal, dengan sistem perakaran yang padat dan arsitektur akar tipeM (Gambar 1), mempunyai potensi yang luar biasa sebagai tanaman pengendali erosi.

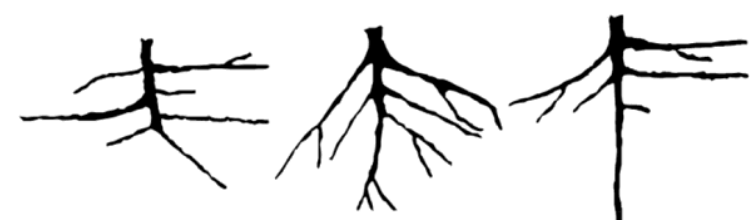

(a) H-type $\quad$ (b) R-type
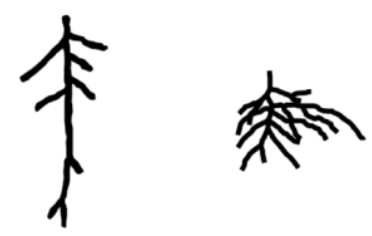

(c) Vi-type

(d) V-type

(e) M-type

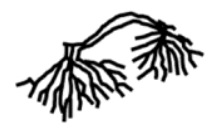

(f) W-type

Gambar 1. Tipe arsitektur perakaran tanaman (Li et al., 2016 modifikasi dari Yen,1987).

Dari pengamatan Setiawan dan Budi (2012), terhadap tanaman berkayu $u_{2}$ Strychnos lucida (bidara laut) memiliki arsitektur perakaran 
tipe-R. Arsitektur perakaran tipe- $R$ menurut klasifikasi Li et al. (2016) (Gambar 1) merupakan tipe yang paling efektif dalam meningkatkan kekuatan geser tanah. Hal ini dibuktikan juga oleh Fan dan Yu-wen (2010) dalam penelitiannya -terhadap 5 species yang berbeda yaitu Hibiscus tiliaceus L., Mallotus japonicus (Thunb.), Sapium sebiferum (L.) Roxb, Casuarina equisetifolia L. dan Leucaena leucocephala dalam meningkatkan kuat geser tanah. Dikatakan bahwa tanaman yang mempunyai arsitektur perakaran tipe- $R$ memberikan peningkatan kuat geser yang paling besar dibanding dengan 4 species lainnya yang mempunyai arsitektur perakaran tipe-V, tipe-VH dan tipe-H.

\subsection{Karakteristik Perakaran Tanaman Dan Peranannya Untuk Mitigasi Gerakan Tanah Dan Erosi}

Perakaran tanaman dapat mengurangi kerentanan terhadap erosi karena mempunyai kemampuan mengikat partikel tanah. Selain itu, perakaran tanaman juga membantu mengurangi air tanah yang jenuh oleh air hujan, memantapkan agregasi tanah sehingga lebih mendukung pertumbuhan tanaman akibatnya tanah tidak mudah hanyut akibat aliran permukaan, meningkatkan infiltrasi, dan kapasitas memegang air. Abdullah, et al. (2011) mengatakan bahwa vegetasi memainkan peranan penting dalam fungsi penguatan dan membentuk rangkaian ikatan pada lapisan tanah. Keberadaan akar tanaman dapat mengurangi tegangan air pori positif dan memperbesar tegangan air pori negatif. Kemampuan ini meningkatkan kekuatan tanah khususnya tegangan geser dalam menjaga kestabilan lereng. Penguatan dan penjangkaran akar ke tanah yang lebih dalam karena sifat mekanik akar akan memberikan efek stabilitas (Gambar 2).

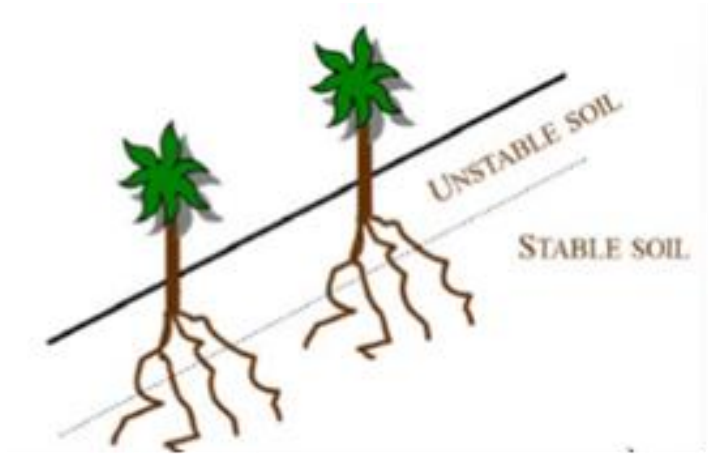

Gambar 2. Efek stabilitas dari akar tanaman (Capilleria et al . 2016).
Kemampuan akar tanaman dalam meningkatkan stabilitas lereng selain melalui penjangkarannya, juga karena akar tanaman mampu menambah kuat geser tanah sehingga akan mampu mengurangi bahaya terjadinya gerakan tanah. Peningkatan kuat geser ini tergantung pada karakteristik akar diantaranya distribusi akar yaitu bagaimana posisi penetrasi akar dalam lapisan tanah dan kondisi akar vertikal dan horizontal, serta pola percabangan akar.

Kondisi akar vertikal dan horizontal dapat digunakan untuk mengetahui daya cengkeram dan penjangkaran akar yang dikenal dengan istliah Indeks Jangkar Akar (IJA) dan Indeks Cengkeram Akar (ICA). IJA dan ICA pada dasarnya dapat digunakan untuk menggambarkan distribusi perakaran suatu jenis tanaman. IJA merupakan perbandingan diameter akar-akar vertikal dan diameter batang, sedangkan ICA adalah perbandingan antara diameter akar-akar horizontal dan diameter batang (Hairiah et. al. 2008). Akar diklasifikasikan sebagai akar horizontal apabila sudut antara akar dan bidang vertikal lebih dari atau sama dengan $45^{\circ}$, sedangkan apabila kurang dari $45^{\circ}$ diklasifikasikan sebagai akar vertikal. Pada umumnya tanaman kayu-kayuan mempunyai akar yang kuat dan dalam, sehingga berpengaruh besar dalam meningkatkan kekuatan tanah untuk menahan gerakan.

Beberapa variabel karakteristik perakaran tanaman yang dapat digunakan dalam menentukan jenis tanaman untuk mitigasi gerakan tanah antara lain adalah IJA, ICA, arsitektur akar dan posisi penetrasi akar.

Dari hasil penelitiannya, Setiawan dan Budi (2012) melaporkan bahwa akar bidara laut (Strychnos lucida, R.Br), mampu menembus lapisan tanah dalam, mempunyai arsitektur akar tipe-R, nilai IJA tinggi dan nilai ICA sedang. Hal ini mengindikasikan bahwa bidara laut mempunyai akar yang mampu memperkuat tanah sehingga meningkatkan kuat geser tanah dan pada akhirnya dapat mengurangi resiko terjadinya gerakan tanah, khususnya gerakan tanah dangkal atau permukaan.

Setiawan dan Krisnawati (2014) menyebutkan beberapa contoh tanaman pohon tropis yang lain, khususnya tanaman buah buahan yang kemungkinan dapat dipilih untuk meningkatkan kuat geser tanah dilihat dari variabel karakteristik nilai IJA dan ICA seperti pada Tabel 1. 
Tabel 1. Indeks jangkar akar (IJA) dan indeks cengkeram akar (ICA) dari beberapa spesies tanaman (Setiawan dan Krisnawati, 2014).

\begin{tabular}{|c|c|c|c|c|}
\hline Nama Spesies & IJA & $\begin{array}{l}\text { Kate } \\
\text { gori }\end{array}$ & ICA & $\begin{array}{l}\text { Kate } \\
\text { gori }\end{array}$ \\
\hline $\begin{array}{l}\text { Aleuritas } \\
\text { moluccana } \\
\text { (kemiri) }\end{array}$ & 0.70 & Sdg & 1.59 & Sdg \\
\hline $\begin{array}{l}\text { Durio zibethinus } \\
\text { (durian) }\end{array}$ & 1.12 & Tgg & 0.89 & Rdh \\
\hline $\begin{array}{l}\text { Persea } \\
\text { americana } \\
\text { (alpukat) }\end{array}$ & 1.38 & Tgg & 2.15 & Sdg \\
\hline $\begin{array}{l}\text { Arthocarpus } \\
\text { heterophyllus } \\
\text { (nangka) }\end{array}$ & 1.42 & Tgg & 3.54 & Tgg \\
\hline $\begin{array}{l}\text { Nephelium } \\
\text { lapaceum } \\
\text { (rambutan) }\end{array}$ & 1.14 & Tgg & 3.78 & Tgg \\
\hline $\begin{array}{l}\text { Gnetum gnemon } \\
\text { (melinjo) }\end{array}$ & 2.18 & Tgg & 1.49 & Rdh \\
\hline $\begin{array}{l}\text { Arthocarpus } \\
\text { altilis (sukun) }\end{array}$ & 0.76 & Sdg & 1.86 & Sdg \\
\hline $\begin{array}{l}\text { Garcinia } \\
\text { mangostama } \\
\text { (manggis) }\end{array}$ & 0.86 & Sdg & 1.96 & Sdg \\
\hline $\begin{array}{l}\text { Lansium, sp } \\
\text { (ceruring) }\end{array}$ & 1.34 & Tgg & 3.98 & Tgg \\
\hline $\begin{array}{l}\text { Achras zapota } \\
\text { (sawo) }\end{array}$ & 0.96 & Sdg & 2.06 & Sdg \\
\hline $\begin{array}{l}\text { Mangifera indica } \\
\text { (mangga) }\end{array}$ & 1.44 & Tgg & 4.08 & Tgg \\
\hline $\begin{array}{l}\text { Callophylum } \\
\text { inophylum } \\
\text { (nyamplung) }\end{array}$ & 2.21 & Tgg & 1.00 & Rdh \\
\hline $\begin{array}{l}\text { Gyrinops verstigi } \\
\text { (gaharu) }\end{array}$ & 0.89 & Sdg & 1.01 & Rdh \\
\hline
\end{tabular}

Abdullah et al. (2011) melaporkan hasil penelitiannya tentang kekuatan geser akar pada beberapa tanaman lereng dari jenis tanaman berkayu. Dikatakan bahwa, tiga spesies tanaman kayu yaitu Akasia mangium (akasia), Dillenia suffruticosa (simpoh air) dan Leucaena leucocephala (lamtoro) memiliki potensi yang sangat baik sebagai tanaman lereng berdasarkan sifat kekuatan geser akar dan tanahnya. Dari ketiga tanaman tersebut, akar Akasia mangium (Gambar 3) memiliki kekuatan geser tertinggi dibandingkan dengan akar Leucaena leucocephala (Gambar 4 dan Dillenia suffruticosa (gambar 5). Sedangkan dari faktor kohesinya, Leucaena leucocephala mempunyai faktor kohesi tertinggi, yang nilainya hampir dua kali lipat dibanding Dillenia suffruticosa dan Acacia mangium. Hal ini sesuai dengan hasil penelitian Ali (2010), bahwa beberapa sifat mekanik dari akar tanaman tropika yaitu Leucaena leucocephala memiliki sifat mekanik akar yang menonjol dan tanaman ini memiliki fitur yang diperlukan untuk menjadi tanaman lereng yang istimewa. Selain sifat mekanik akarnya, tanaman Leucaena leucocephala memiliki morfologi akar yang sangat kokoh, karena akar tunggangnya menembus kuat ke dalam tanah sehingga pohon tidak mudah tumbang oleh tiupan angin.

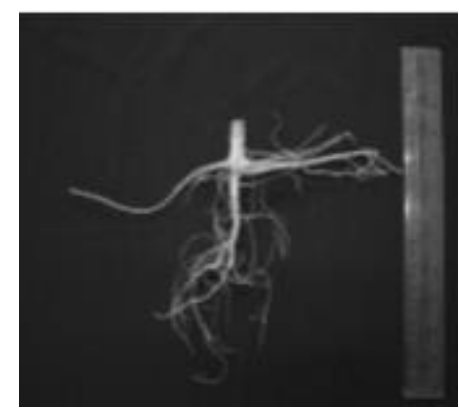

Gambar 3. Akar dari Acasia mangium yang mempunyai kekuatan geser tinggi (Abdullah et al., 2011).

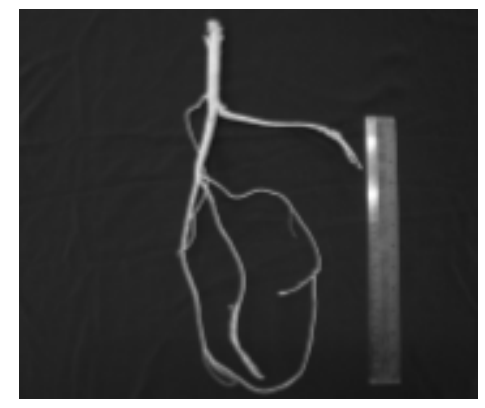

Gambar 4. Akar Leucaena leucocephala mempunyai faktor kohesi tinggi (Abdullah et al., 2011).

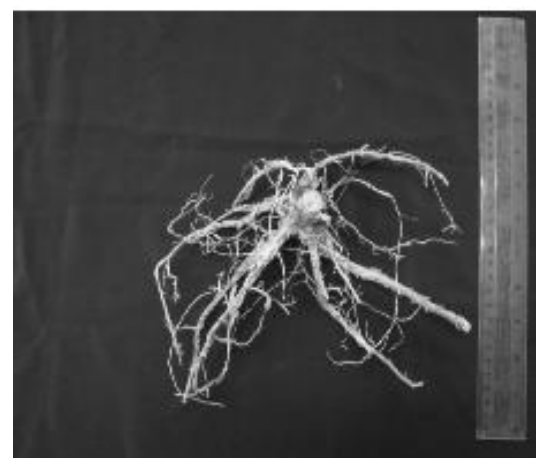

Gambar 5. Akar Dillenia suffructicosa (Abdullah et al., 2011)

Selain tanaman berkayu tersebut diatas, jenis tanaman berkayu dari spesies Pinus 
merkusii secara genetik memiliki akar yang dalam sehingga akarnya dapat menembus ke lapisan yang lebih dalam, relatif ringan dan dapat menjaga stabilitas lereng karena dapat mengurangi beban pada lereng (Indrajaya dan Wuri, 2008). Distribusi akar pohon biasanya dinyatakan dengan pendekatan tinggi pohon dan jari-jari tajuk. Pada daerah dengan tanah pasiran (tekstur kasar), akar pohon dapat menyebar hingga beberapa kali tinggi rata-rata pohon. Untuk pohon pinus yang tumbuh di tanah pasiran, penyebaran akar dapat mencapai tujuh kali dari tinggi rata-rata pohonnya. Sementara itu, pada tanah lempungan (tekstur halus), akar pohon hanya menyebar satu setengah kali tinggi rata-rata pohon (Hardiyatmo, 2006).

\section{KESIMPULAN DAN SARAN}

- Perakaran tanaman melalui mekanisme mekanik dapat meningkatkan kuat geser tanah dan daya kohesi yang memberikan efek positif terhadap peningkatan stabilitas lereng sehingga dapat digunakan sebagai langkah mitigasi untuk bencana gerakan tanah dangkal dan erosi. Pertumbuhan tanaman yang berkelanjutan akan lebih meningkatkan stabilitas lereng seiring dengan waktu melalui pengembangan sistem perakaran, peningkatan hisap tanah dan pengurangan kelembaban tanah.

- Dalam menentukan jenis tanaman untuk aplikasi lapangan, perlu dipertimbangkan beberapa variabel karakteristik perakaran tanaman antara lain nilai Indeks Jangkar Akar (IJA), Indeks Cengkeram Akar (ICA), arsitektur akar dan posisi penetrasi akar. Untuk mendapatkan peningkatan stabilitas lereng yang maksimal, yang perlu diperhatikan juga adalah kontribusi vegetasi, kombinasi jenis tanaman dan metode pemasangannya serta posisi penempatan masing - masing jenis tanaman.

- Tanaman pohon berkayu dari daerah tropika yang mempunyai potensi perakaran untuk mitigasi gerakan tanah dan erosi antara lain yaitu Leucaena leucocephala (lamtoro), Akasia mangium (akasia), Pinus merkusii, Strychnos lucida (bidara laut) beberapa tanaman buah - buahan berkayu seperti Arthocarpus heterophyllus (nangka), Lansium sp (ceruring), Nephelium lapaceum (rambutan), dan Mangifera indica (mangga).
- Pemanfaatan vegetasi untuk meningkatkan stabilitas lereng dan mencegah erosi, mempunyai nilai potensial sebagai cara yang efektif, ekonomis dan ramah lingkungan.

\section{DAFTAR PUSTAKA}

Azizi A. and Salim M. A. 2015. Study of Landslide Mitigation With A Vegetative Method in Binangu Village Banyumas District. (In Indonesian) Techno 16 63-9).

Abdullah, M.N. Normaniza O dan Faisal H.A. 2011. Soil-root Shear Strength Properties of Some Slope Plants. Sains Malaysiana 40(10) (2011): 1065-1073.

Agus, F., Ginting A. N dan M. van Noordwidjk. 2002. Pilihan Teknologi Agroforestri/ Konservasi Tanah Untuk Areal Pertanian Berbasis Kopi di Sumberjaya, Lampung Barat. International Centre for Research in Agroforestry, Bogor.

Ali, F. 2010. Use of Vegetation For Slope Protection: Root Mechanical Properties of Some Tropical Plants. International Journal of Physical Sciences Vol. 5(5), pp. 496-506, May 2010 Available online at http://www.academicjournals.org/lJPS ISSN 1992 - 1950 (C) 2010 Academic Journals.

Collison, A. dan Pollen N. 2005. The Effects of Riparian Buffer Strips On Stream Bank Stability: Root Reinforcement, Soil Strength And Growth Rates. Am. Soc. Agr vol 48pp 15-56.

Chirico, G. B, Marco, B, Paolo, T, Riccardo, R., Federico, P. 2013. Role Of Vegetation On Slope Stability Under Transient Unsaturated Conditions. Procedia Environmental Sciences 19 ( 2013 ) 932 $-941$.

Capilleria, P. P., Ernesto, M., Erminia R. 2016. Experimental Study On Native Plant Root Tensile Strength For Slope Stabilization. Procedia Engineering 158 ( 2016 ) 116 $-121$.

Fan, C. and Yu-wen Chen. 2010. The Effect Of Root Architecture On The Shearing Resistance Of Root Permeated Soil. Ecological Engineering. Vol.36, issue 6, hal : 813-826.

Greenway, D. R. 1987. Vegetation And Slope stability. In Slope Stability, Anderson MG, Richards KS (eds). John Wiley \& Sons: Chichester; 187-230.

Hairiah K, Widianto dan Suprayogo D. 2008. Adaptasi dan Mitigasi Pemanasan Global : Bisakah Agroforestri Mengurangi Risiko 
Longsor Dan Emisi Gas Rumah Kaca. Kumpulan Makalah INAFE, UNS, Surakarta.

Hardiyatmo, H. C. 2006. Penanganan Tanah Longsor dan Erosi. Gadjah Mada University Press. Yogyakarta. Hal. 308319.

Huat B. B. K., Sina K. 2010. Study Of Root Theories In Green Tropical Slope Stability. EJGE. Vol. 15 (2010).

Indrajaya, Y. dan Wuri H. 2008. Potensi Hutan Pinus merkusii Jungh. et de Vriese Sebagai Pengendali Tanah Longsor Di Jawa (Potency of Merkus Pine (Pinus merkusii Jungh. et de Vriese) Forest as Landslide Control in Java). Info Hutan Vol. V No. 3 : 231-240, 2008.

Laela, Astri Rahayu dan Agus Dwidjaka Slope. 2014. Analisis Sabilitas Lereng Dengan Menggunakan Metode Bioteknik Pada Ruas Jalan Tawaeli - Toboli, Infrastruktur, Vol. 4 No.1: 1 - 14 Universitas Tadulako, Palu.

Li, Yunpeng; Yunqi Wang; Chao Ma; Huilan Zhang; Yujie Wang; Shuangshuang Song; Jinqi Zhu. 2016. Influence Of The Spatial Layout Of Plant Roots On Slope Stability, Ecological Engineering, Volume 91, June 2016, pages 477-486, https://doi.org/10.1016/j.ecoleng.2016.02.0 26.

Monteleone, S. dan Sabatino, M. 2014. Hydrogeological Hazards And Weather Events: Triggering And Evolution of Shallow Landslides, International Soil And Water Conservation Research, Volume 2, Issue 2, pp. 23-29.

Reubens, B., Poesen, J., Danjon, F., Geudens, G., dan Muys, B. 2007. The Role Of Fine And Coarse Roots In Shallow Slope Stability And Soil Erosion Control With A Focus On Root System Architecture: A Review, Trees, Volume 21, pp. 385-402.

Setiawan, O dan Budi H. N. 2012. Sistem Perakaran Bidara Laut (Strychnos lucida R.Br) Untuk Pengendalian Tanah Longsor. Jurnal Penelitian Kehutanan Wallacea Vol.1 No.1, Agustus $2012: 50-61$.

Setiawan, O. dan Krisnawati. 2014. Pemilihan Jenis Hasil Hutan Bukan Kayu Potensial Dalam Rangka Rehabilitasi Hutan Lindung KPHL Rinjani Barat, Nusa Tenggara Barat. Jurnal Ilmu Kehutanan. Vol 8. No.2, Juli Sepember 2014.

Sittadewi, E. H. 2010. Penentuan Jenis Vegetasi Lokal Untuk Perlindungan Tebing Sungai Siak Dengan Desain Ekoengineering Tanpa Turap. Jurnal
Teknologi Lingkungan. Vol. 11 No. 2 : 189195.

Stokes A., Ball J, Fitter A. H., Brain P., Coutts M. P. 1996. An Experimental Investigation Of The Resistance Of Model Root Systems To Uprooting. Annals Bot. 78: 415-421.

Susilawati dan Veronika. 2016. Kajian Rumput Vetiver Sebagai Pengaman Lereng Secara Berkelanjutan. Media Komunikasi Teknik Sipil [S.I.]. p. 99-108. doi: http://dx.doi.org/10.14710/mkts.v22i2.1288 6.

Yen, C. P. 1987. Tree Root Patterns And Erosion Control. Proceedings of the International Workshop on Soil Erosion and its Countermeasures. Soil and Water Conservation Society of Thailand, Bangkok.

Zakaria, Z, Dicky M., Raden Irvan Sophian; Sondi K., Ujang H. T. 2013. BioEngineering, Melalui Pemanfaatan Tanaman Kaliandra (Caliandra calothyrsus) Di Wilayah Zona Rawan Longsor Jawa Barat. Bulletin of Scientific Contribution: Geology. Vol. 11. No. 3: 168 - 175. DOI:.https://doi.org/10.24198/ bsc\%20 geology.v11i3.8297.

Ziemer, R. R. 1981. The Role Of Vegetation In The Stability Of Forested Slopes. Proc. Int. XVII IUFRO World Congr. 297-308. 